\title{
Climate change and the oil industry
}

Common problem, different strategies

Jon Birger Skjærseth and Tora Skodvin 


\section{Climate change}

and the oil industry

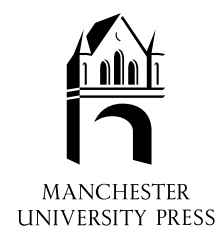




\section{Issues in Environmental Politics}

\section{Series editors Mikael Skou Andersen and Duncan Liefferink}

At the start of the twenty-first century, the environment has come to stay as a central concern of global politics. This series takes key problems for environmental policy and examines the politics behind their cause and possible resolution. Accessible and eloquent, the books make available for a non-specialist readership some of the best research and most provocative thinking on humanity's relationship with the planet.

already published in the series

Science and politics in international environmental regimes

Steinar Andresen, Tora Skodvin, Arild Underdal and Jørgen Wettestad

Congress and air pollution: environmental politics in the US

Christopher J. Bailey

Implementing international environmental agreements in Russia

Geir Hønneland and Anne-Kristin Jørgensen

The protest business? Mobilizing campaign groups

Grant Jordan and William Maloney

Implementing EU environmental policy

Christoph Knill and Andrea Lenschow (eds)

Environmental pressure groups Peter Rawcliffe

North Sea cooperation: linking international and domestic pollution control Jon Birger Skjærseth

European environmental policy: the pioneers

Mikael Skou Andersen and Duncan Liefferink (eds)

Environmental policy-making in Britain, Germany and the European Union Rüdiger K. W. Wurzel 


\section{Climate change and the oil industry}

Common problem, varying strategies

Jon Birger Skjærseth and Tora Skodvin

Manchester University Press

Manchester and New York

distributed exclusively in the USA by Palgrave 
Copyright (C) Jon Birger Skjærseth and Tora Skodvin 2003

The right of Jon Birger Skjærseth and Tora Skodvin to be identified as the authors of this work has been asserted by them in accordance with the Copyright, Designs and Patents Act 1988.

Published by Manchester University Press

Oxford Road, Manchester M13 9NR, UK

and Room 400, 175 Fifth Avenue, New York, NY 10010, USA

www.manchesteruniversitypress.co.uk

Distributed exclusively in the USA by

Palgrave, 175 Fifth Avenue, New York,

NY 10010, USA

Distributed exclusively in Canada by

UBC Press, University of British Columbia, 2029 West Mall,

Vancouver, BC, Canada V6T 1Z2

British Library Cataloguing-in-Publication Data

A catalogue record for this book is available from the British Library

Library of Congress Cataloging-in-Publication Data applied for

ISBN 0719065585 hardback

First published 2003

$\begin{array}{lllllllllllllllllll}11 & 10 & 09 & 08 & 07 & 06 & 05 & 04 & 03 & 10 & 9 & 8 & 7 & 6 & 5 & 4 & 3 & 2 & 1\end{array}$

Typeset in Sabon

by Action Publishing Technology Ltd, Gloucester

Printed in Great Britain

by Bell \& Bain Ltd, Glasgow 